\title{
Perbedaan Regulasi Emosi Berdasarkan Jenis Kelamin dan Rentang Usia pada Remaja dengan Orangtua Bercerai
}

\author{
Gita Maharani Swastika, Endang Prastuti \\ Program Studi Psikologi, Fakultas Pendidikan Psikologi, Universitas Negeri Malang, Malang
}

\begin{abstract}
Abstrak. Remaja memiliki karakteristik emosi yang tidak stabil, namun belum diketahui apakah terdapat perbedaan regulasi emosi ditinjau dari jenis kelamin dan rentang usia remaja (awal, tengah, akhir). Penelitian ini bertujuan untuk mendeskripsikan gambaran serta mengetahui perbedaan regulasi emosi ditinjau dari jenis kelamin dan rentang usia pada remaja dengan orangtua bercerai di Kota Malang. Responden penelitian berjumlah 150 yang terbagi berdasarkan jenis kelamin dan rentang usia. Instrumen penelitian menggunakan skala regulasi emosi yang disusun oleh peneliti. Penelitian ini menggunakan pendekatan kuantitatif dengan jenis penelitian deskriptif komparatif. Hasil penelitian menunjukkan bahwa tidak terdapat perbedaan regulasi emosi ditinjau dari jenis kelamin pada remaja dengan orangtua bercerai di Kota Malang dengan nilai sig ( 2 tailed $)=.540$. Hasil lainnya adalah terdapat perbedaan regulasi emosi ditinjau dari rentang usia pada remaja awal dengan remaja madya serta remaja awal dengan remaja akhir yang memiliki orangtua bercerai di Kota Malang dengan nilai sig ( 2 tailed) $=.005$ dan .000 namun tidak terdapat perbedaan regulasi emosi ditinjau dari rentang usia remaja madya dengan remaja akhir yang memiliki orangtua bercerai di Kota Malang dengan nilai sig ( 2 tailed) $=.989$. Berdasarkan jenis kelamin dan usia, teknik sampling dengan jumlah responden lebih besar dan lebih merata menjadi saran penting bagi penelitian berikutnya, selain keterlibatan variabel strategi regulasi emosi.
\end{abstract}

Kata Kunci: jenis kelamin, regulasi emosi, remaja dengan orangtua bercerai

\section{The Differences of Emotional Regulation Based on Gender and Age Range in Adolescents with Divorced Parents}

Abstract. Adolescents have characteristics of emotion instability however it is not yet known whether emotion regulation difference exists seen from gender and stage of adolescence (early, middle, late). This study aims to describe and to find out the differences of emotion regulation reviewed by gender and age range in adolescents with divorced parents in Malang City. The research respondents amounted to 150 who will be divided by gender and age range. The instrument in this research uses emotion regulation scale made by researcher. This research uses quantitative approaches with the type of descriptive comparative research. The result showed that there are no differences of emotion regulation reviewed by gender in adolescents with divorced parents in Malang City with sig value $(2$ tailed $)=.540$. Other result show that there are differences of emotion regulation reviewed by age range of early adolescents with middle adolescents also early adolescents with end adolescents who has divorced parents in Malang City with sig value ( 2 tailed) $=.005$ and .000 but there are no differences of emotion regulation reviewed by age range middle adolescents with end adolescents who has divorced parents in Malang City with sig value ( 2 tailed $)=.989$. Based on gender and age, the sampling technique with a larger and more even number of respondents is an important suggestion for future research, in addition to the involvement of the emotional regulation strategy variables.

Keywords: adolescents with divorced parents, emotion regulation, gender

Korespondensi: Endang Prastuti. Email: endang.prastuti. fppsi@um.ac.id 
Keluarga merupakan tempat pertama bagi individu untuk belajar, tumbuh dan berkembang baik secara psikis maupun psikologis. Hal ini didukung oleh pengertian keluarga menurut Kamus Besar Bahasa Indonesia (KBBI) bahwa keluarga merupakan satuan kekerabatan yang paling mendasar dalam masyarakat. Kartono (1997) juga menyebutkan bahwa keluarga merupakan suatu organisasi sosial yang paling penting dalam kelompok sosial dan keluarga merupakan lembaga masyarakat yang paling utama bertanggung jawab untuk menjamin kesejahteraan sosial dan kelestarian biologis pada setiap pribadi. Hubungan yang terjalin dalam keluarga juga terjadi secara bertahap mulai dari hubungan antara suami dan istri hingga hubungan antara orangtua dan anak.

Hubungan keluarga yang baik akan memberikan dampak yang positif bagi keadaan anak dalam keluarga tersebut. Hurlock (1973) menyatakan anak yang memiliki orangtua dengan hubungan perkawinan bahagia akan mempersepsikan rumah mereka sebagai tempat yang membahagiakan karena semakin sedikit masalah yang dialami orangtua maka semakin sedikit masalah yang dihadapi anak, dan sebaliknya hubungan keluarga yang buruk akan berpengaruh kepada seluruh keluarga. Berdasarkan pernyataan tersebut dapat disimpulkan bahwa orangtua memiliki peran yang penting dalam kehidupan anak karena anak yang tumbuh dalam keluarga bahagia cenderung memiliki kondisi emosi yang baik.
Fakta di lapangan menunjukkan bahwa banyak keluarga yang mengalami konflik hingga berujung perceraian. Data dari Dirjen Badan Peradilan Agama, Mahkamah Agung periode 2014-2016 mengungkapkan bahwa di Indonesia terjadi peningkatan perceraian yang cukup signifikan. Pada tahun 2014, angka perceraian mencapai 344.237 dan naik menjadi 365.633 pada tahun 2016. Berdasarkan data tersebut dapat dirata-rata kenaikan angka perceraian di Indonesia yaitu 3\% setiap tahunnya. Perceraian tidak hanya terjadi di kota-kota besar yang ada di Indonesia namun juga terjadi di kota-kota kecil seperti Kota Malang. Hal ini didukung oleh data yang diungkapkan salah satu staf pelaporan perkara Pengadilan Agama Kota Malang kepada surat kabar IDN Times yang menunjukkan bahwa sepanjang tahun 2018 tercatat 2109 perkara perceraian yang telah diselesaikan dan diterbitkan akta perceraian di Pengadilan Agama Kota Malang (IDN Times, 2019).

Hal ini semakin memprihatinkan secara psikologis karena dampak yang terjadi akibat perceraian tidak hanya kepada orangtua pelaku perceraian, namun juga pada anak-anak yang ada dalam keluarga tersebut. Bahkan, dampak perceraian tidak hanya berimbas pada masa anak namun juga dapat terbawa hingga individu memasuki masa remaja karena masa perkembangan manusia terjadi secara bertahap dan berpengaruh satu sama lain, terlebih masa remaja merupakan masa peralihan yang sangat penting bagi individu. Hasil penelitian Amato 
et al (1995) menguatkan bahwa semakin tinggi konflik pada orangtua maka semakin rendah kesejahteraan psikologis remaja. Garnefski dan Diekstra (1997) juga menyebutkan bahwa remaja dari keluarga bercerai memiliki harga diri yang rendah, gelisah, kesepian, suasana hati yang lebih tertekan, serta memiliki ide dan usaha bunuh diri dibandingkan remaja dari keluarga utuh. Fakta-fakta ini mengindikasikan adanya problematik regulasi emosi, pada remaja pada orangtua bercerai.

Ketika memasuki usia remaja, anak akan sulit menerima keadaan yang sesungguhnya bahwa keluarganya telah bercerai daripada anak yang memasuki usia dewasa (Lestari, 2014). Kesulitan anak dalam menerima perceraian yang terjadi akan berdampak pada berbagai aspek dalam hidup anak. Salah satu dampaknya adalah pada bagaimana anak menyelesaikan masalah yang dialami. Masalahmasalah yang terjadi dalam kehidupan anak akan berdampak pada bagaimana anak mampu mengelola atau meregulasi emosi. Hal ini dikarenakan keluargalah yang menjadi tempat pembelajaran awal dan faktor terpenting pada pengelolaan emosi anak. Cara individu mengatur emosi yang dimiliki berpengaruh pada bagaimana individu tersebut berhubungan dengan orang lain maupun diri sendiri.

Regulasi emosi merupakan kemampuan individu untuk mengatur perasaan, reaksi fisiologis serta kognisi yang berhubungan dengan emosi yang dimiliki individu. Dampakdampak yang akan terjadi jika seseorang dapat mengelola emosinya dengan baik maka ia dapat memaafkan serta akan mengalami penurunan kemarahan, kecemasan, dan depresi yang signifikan (Astuti et al., 2019). Individu yang memiliki regulasi emosi yang tinggi adalah individu yang mampu mengelola emosi yang dirasakan, sehingga ketika mengalami masalah tidak terpengaruh emosi negatif. Selain itu, seseorang sedang menghadapi stimulus negatif dan individu tersebut dapat mengatur dan menurunkan emosi negatif nya maka perilaku yang muncul adalah bentuk perilaku yang konstruktif, bukan destruktif. Individu yang mampu meregulasi emosinya akan mendapatkan dampak positif bagi kesehatan fisik, tingkah laku, dan hubungan sosial (Endaryani et al, 2020).

Namun sebaliknya, bila seseorang tidak dapat mengelola emosi dengan baik, seseorang akan berperilaku agresif hingga membahayakan keselamatan individu atau bahkan orang lain. Seperti yang diungkapkan oleh Farichah et al. (2019), remaja dengan karakteristik regulasi emosi rendah biasanya memiliki permasalahan dengan teman sebaya di sekitar lingkungan mereka, cenderung bertindak tidak sesuai norma yang ada, misalnya menjadi pelaku perundungan antar teman, mudah menyalahkan orang lain, meluapkan emosinya dengan hal-hal negatif, berkelahi dengan teman, dendam, pasrah, mudah marah, dan putus asa. Serupa dengan pendapat Fitriani dan Alsa (2015), yang mengungkapkan bahwa remaja yang memiliki regulasi emosi rendah dapat mengalami beragam bentuk psikopatologi remaja, baik dari 
gangguan internal, seperti depresi, stres, sedih, cemas, dan gangguan eksternal, seperti perilaku disregulasi dan kemarahan. Berdasarkan paparan tersebut, tampak bahwa regulasi emosi merupakan hal yang krusial dalam perkembangan remaja.

Regulasi emosi dipengaruhi oleh berbagai faktor yakni faktor yang berasal dari luar individu hingga kemampuan individu itu sendiri. Beberapa faktor tersebut antara lain: (a) hubungan orangtua dengan anak; (b) umur dan jenis kelamin; (c) hubungan interpersonal (Zonya \& Sano, 2019). Berdasarkan referensi tersebut, salah satu faktor yang berpengaruh pada regulasi emosi seseorang adalah jenis kelamin (gender). Perempuan dikatakan lebih emosional dibandingkan dengan laki-laki. Hal ini dibuktikan melalui beberapa penelitian mengindikasikan bahwa perempuan lebih responsif secara emosional dibandingkan lakilaki (Bradley et al, 2001; Fujita et al., 1991; Lucas \& Gohm, 2000; Seidlitz \& Diener, 1998). Penelitian lain yang dilakukan oleh Brody (1997) juga menunjukkan bahwa berdasarkan kepercayaan yang terdapat di masyarakat, terdapat bukti bahwa perempuan lebih banyak menunjukkan ekspresi emosional dibandingkan dengan laki-laki.

Faktor lain yang mempengaruhi regulasi emosi individu adalah usia dari individu tersebut. Hal ini dibuktikan melalui penelitian mengenai regulasi emosi bahwa bertambahnya usia individu akan berkorelasi dengan peningkatan kemampuan regulasi emosi. Oleh karena itu, menurut Maider (Coon, 2005), semakin tinggi usia individu, semakin baik kemampuan regulasi emosinya. Hal ini sejalan dengan hasil penelitian Silvers et al. (2012) bahwa usia juga berpengaruh dalam regulasi emosi seseorang. Hal ini diperkuat oleh pendapat Gross (2008) bahwa semakin bertambahnya usia maka semakin baik pula regulasi emosinya.

Ditinjau dari perspektif perkembangan, masa perkembangan manusia menjadi dibagi beberapa periode yakni periode kelahiran hingga periode dewasa akhir, di mana fase perkembangan yang terjadi dalam kehidupan individu tersebut saling berkaitan satu sama lain. Salah satu masa perkembangan yang paling beresiko adalah masa remaja (Santrock, 2012). Selanjutnya, Santrock (2012) juga mengatakan bahwa masa remaja merupakan masa transisi dari anak-anak menjadi dewasa, ditandai adanya perubahan yang besar dalam berbagai aspek perkembangan. Perubahan dalam keluarga (keluarga yang bercerai) diduga akan berpengaruh pada kemampuan regulasi emosi pada anak.

Remaja dengan orangtua bercerai diharapkan memiliki kemampuan regulasi emosi sehingga memiliki kemampuan beradaptasi dan mengatasi masalah yang terjadi dalam hidupnya serta mampu mengelola emosi yang dirasakan, terutama ketika menghadapi kondisi penuh tekanan. Namun, kenyataannya, kebanyakan remaja korban perceraian orangtua cenderung memiliki regulasi emosi 
yang rendah. Hal ini diperkuat Hetherington (Dagu, 2002) bahwa peristiwa perceraian akan menimbulkan dampak pada emosi anak yang ditandai dengan ketidakstabilan emosi, mengalami rasa cemas, tertekan dan sering marah-marah, yang mengindikasikan adanya problematik dalam meregulasi emosi.

Hal ini menjadi keterbaruan dalam penelitian ini karena karakteristik responden penelitian dengan latar belakang keluarga bercerai. Sebelumnya, regulasi emosi di Indonesia fokus pada karakteristik responden yang berbeda, misalnya wanita dengan perimenopause (Aris \& Rinaldi, 2015), siswa sekolah (Pratama, 2019), maupun santri di pondok pesantren (Nansi \& Utami, 2016).

Berdasarkan paparan di atas, penelitian ini bertujuan: (1) untuk mengetahui gambaran regulasi emosi berdasarkan jenis kelamin; (2) mengetahui gambaran regulasi emosi berdasarkan rentang usia remaja: remaja awal, madya dan akhir; dan (3) untuk mengetahui perbedaan regulasi emosi ditinjau dari jenis kelamin dan rentang usia remaja (remaja awal, remaja madya dan remaja akhir).

\section{Metode}

Penelitian ini menggunakan pendekatan kuantitatif dengan jenis penelitian deskriptif komparatif. Rancangan penelitian ini mengukur perbedaan regulasi emosi ditinjau dari jenis kelamin dan rentang usia pada remaja dengan orangtua bercerai. Variabel independen dalam penelitian ini adalah jenis kelamin dan rentang usia sedangkan variabel dependen dalam penelitian ini adalah regulasi emosi. Penelitian ini bertujuan untuk mengetahui perbedaan regulasi emosi ditinjau dari jenis kelamin dan rentang usia pada remaja dengan orangtua mengalami perceraian.

\section{Sampel penelitian}

Populasi dalam penelitan ini adalah remaja dengan orangtua bercerai, berusia 12 22 tahun yang berdomisili di Kota Malang, total berjumlah 150 responden. Teknik sampling yang digunakan dalam penelitian ini adalah quota sampling. Pengambilan sampel menggunakan teknik quota sampling dilakukan karena mempertimbangkan waktu, tenaga, dana serta data yang tidak memuat jumlah keseluruhan remaja dengan orangtua bercerai.

Pengumpulan data dilakukan dengan menggunakan satu instrumen yaitu skala regulasi emosi yang dikembangkan oleh peneliti merujuk pada teori Thompson (1994), terdiri dari 24 butir. Setelah dilakukan uji coba, diperoleh 23 butir yang terpakai dengan indeks daya beda butir bergerak dari .303 - .699 dan koefisien Alpha Cronbach sebesar .901.

\section{Analisis data}

Analisis data yang digunakan dalam penelitian ini yaitu analisis data independentsample t-test untuk menguji perbedaan regulasi emosi berdasarkan jenis kelamin dan one way anova untuk menguji perbedaan regulasi emosi ditinjau dari jenis kelamin serta rentang usia remaja (remaja awal, remaja madya dan remaja akhir). 


\section{Hasil}

Penelitian ini bertujuan untuk: (1) Mengetahui gambaran regulasi emosi berdasarkan jenis kelamin; (2) Mengetahui gambaran regulasi emosi berdasarkan rentang usia remaja: remaja awal, madya dan akhir; dan (3) Untuk mengetahui perbedaan regulasi emosi ditinjau dari jenis kelamin dan rentang usia remaja (remaja awal, remaja madya dan remaja akhir). Analisa menunjukkan hasil-hasil sebagai berikut:

\section{Hasil analisis deskriptif: Regulasi emosi remaja berdasarkan jenis kelamin}

\section{Tabel 1}

Deskripsi Regulasi Emosi Berdasarkan Jenis Kelamin

\begin{tabular}{ccc}
\hline Jenis Kelamin & $\%$ & Kategorisasi \\
\hline \multirow{2}{*}{ Laki-laki } & 44.10 & Tinggi \\
& 55.90 & Rendah \\
\multirow{2}{*}{ Perempuan } & 52.75 & Tinggi \\
& 47.25 & Rendah \\
\hline
\end{tabular}

Tabel 1 menjelaskan bahwa remaja perempuan $(52,75 \%)$ dengan orangtua bercerai memiliki regulasi emosi yang tinggi dibandingkan dengan remaja laki-laki (44.10\%). Artinya, ditinjau dari jenis kelamin terbukti jenis kelamin perempuan lebih memiliki prosentase lebih tinggi dalam regulasi emosi. Berbeda dengan remaja perempuan, sebagian besar remaja laki-laki $(55,9 \%)$ dari orangtua bercerai, memiliki regulasi emosi yang berada dalam kategori rendah. Berdasarkan data Tabel 1 dapat disimpulkan, sebagian besar remaja perempuan, memiliki regulasi emosi tinggi, sementara sebagian besar remaja laki-laki, memiliki regulasi emosi yang rendah.

\section{Tabel 2}

Perbedaan Regulasi Emosi Berdasarkan Jenis Kelamin

\begin{tabular}{ccc}
\hline Jenis Kelamin & $M$ & $S D$ \\
\hline Laki-laki & 65.34 & 9.087 \\
Perempuan & 64.40 & 9.235 \\
\hline
\end{tabular}

Tabel 2 menunjukkan bahwa remaja perempuan memiliki skor rata-rata sebesar 64.40 dengan standar deviasi 9.235, sedangkan remaja laki-laki memiliki skor rata-rata 65.34 dengan standar deviasi 9.087. Hasil uji hipotesis membuktikan bahwa tidak terdapat perbedaan regulasi emosi ditinjau dari jenis kelamin pada remaja dengan orangtua bercerai. Hal ini ditunjukkan dengan hasil uji hipotesis dengan two-tailed diperoleh signifikansi sebesar .540 ( $p>.05)$, maka hipotesis awal yang diajukan dalam penelitian ini ditolak. Hal ini berarti tidak 
ada perbedaan regulasi emosi ditinjau dari jenis kelamin.

\section{Hasil analisis deskriptif: Regulasi emosi berdasarkan rentang usia}

Tabel 3 memberikan informasi bahwa berdasarkan analisis deskriptif pada masing- masing rentang usia diketahui bahwa sebesar $52.9 \%$ responden yang berada pada fase remaja awal memiliki regulasi emosi dalam kategori rendah. Sedangkan, hasil penelitian ini juga tidak berbeda jauh dengan remaja yang berada dalam fase remaja madya, di mana sebanyak $52.4 \%$ remaja

\section{Tabel 3}

Data Regulasi Emosi Berdasarkan Rentang Usia Remaja

\begin{tabular}{ccc}
\hline Fase Remaja & $\%$ & Level Regulasi Emosi \\
\hline Remaja Awal & 52.9 & Rendah \\
Remaja Tengah & 52.4 & Rendah \\
Remaja Akhir & 52.7 & Tinggi \\
\hline
\end{tabular}

madya juga memiliki regulasi emosi dalam kategori rendah. Namun, hasil berbeda ditunjukkan pada remaja yang berada dalam fase remaja akhir. Hasil analisis deskriptif regulasi emosi remaja dengan orangtua bercerai yang berada dalam fase remaja akhir menunjukkan sebanyak 52.7\% remaja akhir memiliki regulasi emosi yang termasuk dalam kategori tinggi. Berdasarkan hal tersebut dapat ditarik kesimpulan bahwa remaja yang berada dalam fase remaja awal dan madya memiliki regulasi emosi yang termasuk dalam kategori rendah sedangkan remaja yang termasuk dalam fase remaja akhir memiliki regulasi emosi yang termasuk dalam kategori tinggi.

\section{Tabel 4}

Skor Rata-Rata Regulasi Emosi Berdasarkan Rentang Usia

\begin{tabular}{ccc}
\hline Fase Remaja & $M$ & $S D$ \\
\hline Remaja Awal & 56.53 & 11.495 \\
Remaja Madya & 65.57 & 7.180 \\
Remaja Akhir & 65.87 & 8.515 \\
\hline
\end{tabular}

Tabel 4 menjelaskan bahwa hasil analisis deskriptif berdasarkan rentang usia juga menunjukkan bahwa remaja yang berada dalam fase awal memiliki skor rata-rata sebesar 56.53 dengan standar deviasi 11.495, remaja yang berada dalam fase madya memiliki skor rata-rata sebesar 65.57 dengan standar deviasi 7.180, sedangkan remaja yang berada dalam fase akhir memiliki skor ratarata sebesar 65.87 dengan standar deviasi 8.515. Hal ini berarti perbedaan usia akan berdampak pada regulasi emosi, utamanya perbedaan antara remaja awal dan remaja akhir lebih mencolok. 


\section{Hasil analisis perbedaan regulasi emosi berdasarkan usia}

Berdasarkan hasil uji hipotesis dalam penelitian ini membuktikan bahwa secara keseluruhan terdapat perbedaan regulasi emosi ditinjau dari rentang usia, pada remaja dengan orangtua bercerai. Hal ini ditunjukkan pada data hasil uji hipotesis sebagai berikut:

Uji hipotesis (1) Perbedaan regulasi emosi remaja awal dengan remaja madya, diperoleh signifikansi two-tailed sebesar .005. Maknanya adalah dengan nilai signifikansi kurang dari .05, maka hipotesis awal yang diajukan dalam penelitian ini diterima, yaitu ada perbedaan regulasi emosi antara remaja awal dengan remaja madya.

Uji hipotesis (2) Perbedaan regulasi emosi remaja awal dengan remaja akhir diperoleh signifikansi two-tailed sebesar .000 . Maknanya adalah dengan nilai signifikansi kurang dari .05, maka hipotesis awal yang diajukan dalam penelitian ini diterima, yaitu ada perbedaan regulasi emosi antara remaja awal dengan remaja akhir.

Uji hipotesis (3) Perbedaan regulasi emosi remaja madya dengan remaja akhir diperoleh signifikansi two-tailed sebesar .989. Maknanya adalah dengan nilai signifikansi lebih dari .05, maka hipotesis awal yang diajukan dalam penelitian ini ditolak, yaitu tidak ada perbedaan regulasi emosi antara remaja madya dan remaja akhir. Hasil analisis membuktikan bahwa secara keseluruhan dapat disimpulkan terdapat perbedaan regulasi emosi ditinjau dari rentang usia, pada remaja dengan orangtua bercerai.

\section{Pembahasan}

\section{Regulasi emosi ditinjau dari jenis kelamin}

Hasil penelitian menunjukkan bahwa tidak terdapat perbedaan regulasi emosi ditinjau dari jenis kelamin pada remaja dengan orangtua bercerai. Hasil uji hipotesis diperoleh signifikansi two-tailed sebesar .540 ( $p>.05)$. Hal ini berarti bahwa regulasi emosi yang dimiliki remaja perempuan dan laki-laki dengan orangtua bercerai, tidak berbeda secara signifikan.

Hasil penelitian ini berbanding terbalik dengan hasil penelitian sebelumnya bahwa ada perbedaan regulasi emosi antara perempuan dan laki-laki (Ratnasari \& Suleeman, 2017). Hal ini diduga karena jumlah remaja perempuan dan laki-laki dalam penelitian ini memiliki jumlah yang tidak seimbang. Selain itu, penelitian ini lebih fokus pada kemampuan regulasi emosi, dengan dugaan awal regulasi emosi berbeda terkait gender (jenis kelamin). Meskipun demikian, keterbatasan dari penelitian ini, tidak dikaitkan dengan bagaimana strategi regulasi emosi yang digunakan responden. Temuan menunjukkan bahwa strategi regulasi emosi, wanita lebih banyak menggunakan strategi regulasi dibanding dengan laki-laki. Selain itu penggunaan strategi suppression (penekanan) meningkat seiring usia pada wanita, tetapi tidak pada laki-laki dan penggunaan strategi acceptance (penerimaan) tidak menurun seiiring usia, terutama pada wanita (Nolen-Hoeksema \& Aldao, 2011). 
Hal ini diperkuat dengan data deskriptif yang menunjukkan bahwa lebih dari 50\% remaja laki-laki memiliki skor total regulasi emosi berada pada kategori rendah. Rendahnya skor total tersebut karena remaja laki-laki dalam penelitian ini kurang mampu mengenali, mengendalikan dan mengatur emosi yang akan diekspresikan, namun keterbatasan penelitian ini tidak menjelaskan strategi regulasi yang digunakan apakah adaptif atau sebaliknya.

Tidak adanya perbedaan yang signifikan antara regulasi emosi remaja perempuan dan laki-laki dalam penelitian dikuatkan dengan data deskriptif yang menunjukkan bahwa ratarata skor total regulasi emosi pada responden perempuan yaitu sebesar 64.40 dengan standar deviasi 9.235, sedangkan rata-rata yang regulasi emosi responden laki-laki yaitu sebesar 65.34 dengan standar deviasi 9.087 sehingga dapat disimpulkan bahwa perbedaan rata-rata skor total yang didapatkan responden perempuan dengan responden laki-laki hanya sekitar .94 sedangkan apabila dilihat dari nilai standar deviasi hanya berbeda .148 yang artinya perbedaan tersebut sangat tipis dan diduga menjadi salah satu alasan mengapa dalam penelitian ini regulasi emosi antara perempuan dan laki-laki tidak berbeda secara signifikan.

Hasil penelitian menguatkan fakta bahwa perbedaan regulasi emosi tidak cukup kuat dipengaruhi oleh jenis kelamin, namun terdapat variabel lain yang lebih mampu menjelaskan, salah satunya adalah strategi yang digunakan dalam melakukan regulasi emosi. Hasil penelitian membuktikan regulasi emosi remaja perempuan dengan orangtua bercerai, berada dalam kategori tinggi diduga karena kemampuan remaja perempuan dalam mengenali, mengendalikan dan mengatur emosi sedikit lebih baik dibandingkan dengan remaja laki-laki. Namun, tidak sedikit remaja perempuan dengan orangtua bercerai memiliki kemampuan regulasi emosi yang rendah.

Sementara itu, regulasi emosi remaja lakilaki dalam penelitian ini lebih banyak yang berada dalam kategori rendah. Temuan berbeda, menunjukkan bahwa strategi regulasi emosi akan berbeda ketika responden berusia dewasa. Hal ini diperkuat dengan penelitian berbasis cross-sectional approach dengan membandingkan strategi regulasi emosi pada responden wanita dewasa. Hasil penelitian menunjukkan wanita dengan usia semakin tua lebih sedikit menggunakan supression strategy dibandingkan wanitayang lebih muda usianya. Jadi, seiring dengan bertambahnya usia maka akan meningkatkan strategi regulasi emosi re-appraisal dan mengurangi penggunaan strategi suppression (John \& Gross, 2004).

Implikasi dari temuan ini adalah bahwa seluruh responden baik remaja laki-laki maupun remaja perempuan masih dipandang perlu untuk meningkatkan kemampuan regulasi emosi di dalam dirinya dan masih memerlukan bantuan dari pihak-pihak terkait mengingat usia mereka yang masih sangat muda serta untuk memperbaiki kemampuan regulasi emosi yang dimiliki. Remaja yang mempunyai kemampuan regulasi emosi ditandai dengan hal-hal berikut: 
dapat mengetahui apa yang dirasakan, dipikirkan dan apa yang menjadi latar belakang dalam melakukan suatu tindakan, mampu untuk mengevaluasi emosi-emosi yang dialami sehingga bertindak secara rasional bukan emosional dan mampu untuk memodifikasi emosi yang dialami (Thompson, 1994).

Kedua kelompok responden menunjukkan kemampuan regulasi emosi yang berbeda dilihat dari indikator dalam aspek regulasi emosi. Namun demikian, meskipun menunjukkan kemampuan yang berbeda, perbedaan tersebut tidaklah signifikan. Hal ini didukung dengan perbandingan antara remaja yang memiliki regulasi emosi dalam kategori tinggi dan rendah kurang dari 50\%. Artinya, meskipun remaja perempuan cenderung memiliki regulasi emosi dalam kategori tinggi namun hal tersebut tidak jauh berbeda dengan remaja laki-laki yang memiliki regulasi emosi pada kategori rendah.

Berdasarkan pemaparan di atas, dapat disimpulkan bahwa tidak terdapat perbedaan yang signifikan antara regulasi emosi remaja perempuan dengan remaja laki-laki dengan orangtua bercerai. Implikasi dari temuan ini, masih dirasakan perlu remaja laki-laki maupun perempuan untuk memilih strategi regulasi emosi yang efektif. Sesuai dengan temuan penelitian diharapkan dapat menjadi rujukan bagi remaja yang orangtua bercerai dalam menentukan regulasi emosi yang tepat untuk dirinya saat menghadapi masalah yang dihadapi hingga menjadi ketrampilan (skill) melalui proses belajar dan pelatihan (training).
Hasil penelitian menguatkan bahwa emotion-regulation skill dapat mencegah problem kesehatan mental (Berking et al., 2010), untuk penelitian selanjutnya program ini dapat dimodifikasi atau direplikasi untuk meningkatkan emotion regulation skill pada remaja dengan orangtua bercerai, khususnya pada remaja awal (usia 12-15 tahun).

\section{Regulasi emosi ditinjau dari rentang usia}

Hasil analisis yang pertama didapatkan signifikansi two-tailed sebesar .005 antara remaja awal dengan remaja madya. Hasil ini menunjukkan bahwa hipotesis awal yang diajukan dalam penelitian ini diterima. Dengan kata lain, terdapat perbedaan regulasi emosi antara remaja rentang awal dengan remaja madya. Selanjutnya, didapatkan hasil signifikansi two-tailed sebesar .000 antara remaja awal dengan remaja akhir. Hal ini menunjukkan bahwa hipotesis awal dalam penelitian ini diterima dimana hipotesis yang diajukan adalah ada perbedaan tingkat regulasi emosi remaja awal dengan remaja akhir. Namun, terdapat sedikit perbedaan antara hasil ketiga dengan dua hasil signifikansi two-tailed sebelumnya.

Hasil signifikansi two-tailed yang diperoleh dari remaja madya dengan remaja akhir menunjukkan bahwa hipotesis awal yang diajukan dalam penelitian ini ditolak karena memperoleh hasil signifikansi two-tailed sebesar .989.

Hasil penelitian yang menunjukkan adanya perbedaan antara regulasi emosi remaja 
awal dengan remaja madya dan regulasi emosi remaja rentang awal dengan remaja akhir sesuai dengan hasil penelitian dilakukan oleh Rubiani dan Sembiring (2018) yang menyatakan bahwa terdapat perbedaan antara regulasi emosi ditinjau dari faktor usia. Namun, hasil tersebut juga berbanding terbalik dengan hasil uji komparatif antara remaja madya dengan remaja akhir dimana menurut uji komparatif tidak terdapat perbedaan regulasi emosi antara remaja rentang usia 16-18 tahun dengan remaja rentang usia 19-22 tahun.

Rendahnya kemampuan regulasi emosi pada remaja yang berada dalam fase remaja awal dan madya dengan orangtua bercerai, diduga karena kurangnya kemampuan remaja dalam memahami, menyeimbangkan serta mengatur emosi yang akan diekspresikan terkait dengan usianya yang sangat muda. Berbanding dengan remaja awal dan madya yang memiliki kemampuan regulasi emosi dalam kategori rendah, remaja yang berada dalam fase akhir memiliki tingkat regulasi emosi yang tinggi karena kemampuannya dalam memahami, menyeimbangkan serta mengatur emosi yang akan diekspresikan jauh lebih baik dibandingkan dengan remaja yang berada dalam fase awal dan madya karena bertambahnya usia maka regulasi emosi yang dimiliki juga akan semakin matang.

Hal ini sejalan dengan telaah literatur bahwa menurut Cartesen (Gross, 1998) proses regulasi emosi meningkat seiring usia. Hasil penelitian pada periode dewasa juga menguatkan bahwa usia dewasa akhir dilaporkan memiliki level kesejahteraan (wellbeing) lebih tinggi dibandingkan dewasa muda dikarenakan meningkatnya kemampuan meregulasi emosi, terutama dalam memilih dan mengoptimalkan proses regulasi emosi (Urry \& Gross, 2010).

Penelitian regulasi emosi pada responden remaja membuktikan bahwa kemampuan regulasi emosi akan semakin tinggi seiring dengan meningkatnya usia remaja. Hal ini memperkuat hasil penelitian sebelumnya bahwa remaja akhir memiliki regulasi emosi yang lebih baik dibandingkan remaja madya, sementara regulasi emosi remaja madya tergolong normal dari pada regulasi emosi remaja awal yang tergolong rendah (Rubiani \& Sembiring, 2018). Sementara itu, penelitian ini membuktikan regulasi emosi remaja akhir lebih baik dibandingkan regulasi emosi remaja madya dan remaja awal sehingga dapat ditarik kesimpulan bahwa dalam penelitian ini remaja akhir memiliki kemampuan regulasi emosi yang lebih baik dibandingkan remaja awal dan madya.

Penelitian ini memiliki hasil yang sedikit berbeda dengan penelitian yang ada sebelumnya karena jumlah remaja awal, madya dan akhir dalam penelitian ini memiliki jumlah yang tidak seimbang. Selain itu, dibandingkan dengan remaja awal, remaja akhir yang memiliki skor total yang tidak terlalu berbeda jauh dengan remaja madya. Hal ini dibuktikan melalui hasil rata-rata yang didapatkan dari remaja akhir 
memiliki perbedaan yang sangat tipis apabila dibandingkan dengan hasil rata-rata yang dimiliki remaja madya yakni sebesar .30 dan perbedaan standar deviasi sebesar 1.335, sedangkan remaja yang berada dalam fase awal dan madya memiliki perbedaan yang sesuai dengan penelitian sebelumnya.

Regulasi emosi remaja madya dan akhir dengan orangtua bercerai berada dalam kategori tinggi diduga karena kemampuan remaja madya dan akhir dalam mengenali, mengendalikan dan mengatur emosi sedikit lebih baik dibandingkan dengan remaja awal. Namun, tidak sedikit pula remaja madya dan akhir dengan orangtua bercerai yang memiliki kemampuan regulasi emosi pada kategori rendah. Sedangkan, regulasi emosi remaja awal dalam penelitian ini lebih banyak yang berada dalam kategori rendah. Hal ini menunjukkan bahwa dari seluruh responden penelitian, baik remaja awal, remaja madya maupun remaja akhir masih perlu memperoleh program pelatihan regulasi emosi (emotion regulation training) untuk meningkatkan kemampuan regulasi emosi, hingga menjadi sebuah skill (keterampilan otomatis).

Thompson (1994) menjelaskan bahwa remaja yang mempunyai kemampuan meregulasi emosi dapat mengetahui apa yang dirasakan, dipikirkan dan apa yang menjadi latar belakang dalam melakukan suatu tindakan, mampu untuk mengevaluasi emosi-emosi yang dialami sehingga bertindak secara rasional bukan emosional dan mampu untuk memodifikasi emosi yang dialami. Ketiga kelompok responden menunjukkan kemampuan regulasi emosi yang berbeda dilihat dari indikator dalam aspek regulasi emosi. Dua kelompok responden menunjukkan perbedaan regulasi emosi sedangkan satu kelompok lainnya tidak menunjukkan perbedaan tersebut. Hal ini didukung dengan perbandingan antara remaja yang memiliki regulasi emosi dalam kategori tinggi dan rendah kurang dari 50\%. Artinya, meskipun remaja akhir cenderung memiliki regulasi emosi dalam kategori tinggi, hal tersebut tidak jauh berbeda dengan remaja awal dan madya yang memiliki regulasi emosi dalam kategori rendah.

Keterbatasan dalam penelitian ini tidak menekankan pada pengukuran strategi regulasi emosi yang adaptif dan maladaptif. Secara teoritik, umumnya bentuk regulasi emosi yang adaptif seperti re-appraissal memberi manfaat terkait fungsi afektif, interaksi sosial dan kesejahteraan (well-being), sebaliknya expressive suppression memiliki dampak sebaliknya (Gross \& John, 2003). Dengan demikian disarankan untuk penelitian berikutnya dilakukan pengukuran tidak hanya regulasi emosi, tetapi juga strategi regulasi emosi (adaptif dan maladaptif), untuk diuji apakah ada perbedaan terkait rentang usia remaja (remaja awal, remaja madya, remaja akhir).

Kontribusi dari penelitian ini bahwa terdapat perbedaan regulasi emosi ditinjau dari rentang usia pada remaja dengan orangtua bercerai. Implikasi temuan ini dapat menjadi rujukan bagi remaja dengan orangtua bercerai 
untuk menentukan bagaimana cara melakukan regulasi emosi yang tepat saat menghadapi masalah. Upaya untuk membantu meningkatkan skill (keterampilan) regulasi emosi pada remaja adalah dengan mempertimbangan fase perkembangan remaja (remaja awal, remaja madya, remaja akhir). Merujuk pada temuan penelitian ini, fase remaja awal memiliki skor regulasi emosi lebih rendah dibandingkan dengan fase remaja madya dan akhir. Oleh karena itu, untuk penelitian selanjutnya target pelatihan regulasi emosi lebih diprioritaskan pada remaja awal (12-15 tahun).

\section{Simpulan}

Penelitian ini bertujuan: (1) Untuk mengetahui gambaran regulasi emosi berdasarkan jenis kelamin; (2) Mengetahui gambaran regulasi emosi berdasarkan rentang usia remaja: remaja awal, madya dan akhir; dan (3) Untuk mengetahui perbedaan regulasi emosi ditinjau dari jenis kelamin dan rentang usia remaja (remaja awal, remaja madya dan remaja akhir). Penelitian ini menyimpulkan bahwa: (1) Sebagian besar remaja perempuan dengan orangtua bercerai, memiliki regulasi emosi berada pada kategori tinggi, sedangkan sebagian besar remaja laki-laki memiliki regulasi emosi berada dalam kategori rendah. Berdasarkan rentang usia, sebagian besar remaja awal dan madya dengan orangtua bercerai memiliki regulasi emosi yang berada dalam kategori rendah, sedangkan remaja akhir dengan orangtua bercerai memiliki regulasi emosi pada kategori tinggi; (2) Tidak terdapat perbedaan regulasi emosi ditinjau dari jenis kelamin pada remaja dengan orangtua bercerai. Hal ini dapat diartikan bahwa dalam penelitian ini jenis kelamin tidak dapat membedakan kemampuan regulasi dari seseorang karena hasil skor yang diperoleh memiliki perbedaan yang sangat tipis (tidak signifikan); dan (3) Berdasarkan rentang usia remaja, terdapat perbedaan regulasi emosi ditinjau dari rentang usia pada remaja dengan orangtua bercerai. Hal ini berarti: rentang usia dapat membedakan kemampuan regulasi emosi seseorang karena hasil skor yangdiperoleh memiliki perbedaan yang cukup tinggi kecuali regulasi emosi pada remaja madya dengan remaja akhir.

\section{Saran}

Merujuk pada temuan penelitian, maka disarankan: (1) Bagi remaja (laki-laki) dengan orangtua bercerai diharapkan dapat meningkatkan kemampuan regulasi emosi, dengan proses belajar dan latihan agar dapat menyelesaikan masalah-masalah yang dihadapi dengan lebih positif dan efektif; dan (2) Bagi peneliti selanjutnya disarankan untuk menyempurnakan keterbatasan dalam penelitian ini terkait teknik sampling, dengan jumlah responden yang lebih besar dan lebih memperhatikan pemerataan dari responden yang akan diteliti baik dari jenis kelamin maupun rentang usia. Selain itu, variabel yang dilibatkan dalam penelitian, tidak hanya mengukur regulasi emosi, tetapi juga strategi 
regulasi emosi, merujuk konsep teori yang relevan (misalnya teori Gross (1998)). Agar lebih bermakna secara empiris, penelitian selanjutnya dapat mengembangkan emotion regulation skill training untuk meningkatkan regulasi emosi khususnya pada remaja awal (usia 12-15 tahun).

\section{Referensi}

Amato, P. R., Loomis, L. S., \& Booth, A. (1995). Parental divorce, marital conflict, and offspring well-being during early adulthood. Social Forces, 73(3), 895-915. https://doi.org/10.2307/2580551

Aris, D., \& Rinaldi. (2015). Hubungan regulasi emosi dengan penerimaan diri wanita premenopause. Jurnal RAP, 6(1), 11-22. h ttp s: / / doi.org / 10.24036 / rapun.v6i1.6646

Astuti, D., Wasidi, \& Shintia, R. (2019). Hubungan antara regulasi emosi dengan perilaku memaafkan pada siswa sekolah menengah pertama. Consilia: Jurnal Ilmiah Bimbingan Dan Konseling, 2(1), 1-10. https://doi.org/ 10.33369/consilia.2.1.1-11

Berking, M., Meier, C., \& Wupperman, P. (2010). Enhancing emotion-regulation skills in police officers: Results of a pilot controlled study. Behavior Therapy, 41(3), 329-339. https://doi.org/ 10.1016/j.beth.2009.08.001

Bradley, M. M., Codispoti, M., Sabatinelli, D., \& Lang, P. J. (2001). Emotion and motivation II: Sex differences in picture processing. Emotion, 1(3), 300-319. https:// doi.org/10.1037/15283542.1.3.300

Brody, L. R. (1997). Gender and emotion: Beyond stereotypes. Journal of Social Issues, 53(2), 369-393. https://doi.org/ 10.1111/0022-4537.00022

Coon, D. (2005). Psychology a journey (2nd ed.). Thomson Wadsworth.
Dagu, S. M. (2002). Psikologi keluarga. Rineka Cipta.

Endaryani, V., Yuniardi, M., \& Syakarofath, N. (2020). Pelatihan antecedent-focused \& response-focused untuk meningkatkan regulasi emosi pada remaja panti asuhan. Gadjah Mada Journal of Professional Psychology (GamaJPP), 6(1), 18-29. https: / / doi.org / 10.22146 / gamajpp.55232

Farichah, I. N., Habsy, B. A., \& Suroso, D. H. (2019). Konseling kelompok rasional emotif perilaku dalam membantu mengatasi regulasi emosi siswa SMP, efektifkah? Jurnal Pendidikan, 4(1), 25-32. https:// doi.org/10.26740/jp.v4n1.p25-32

Fitriani, Y., \& Alsa, A. (2015). Relaksasi autogenik untuk meningkatkan regulasi emosi pada siswa SMP. E-Jurnal GamaJpp, 1(3), 149-162. https://doi.org/10.22146/gamajpp.9391

Fujita, F., Diener, E., \& Sandvik, E. (1991). Gender differences in negative affect and well-being: The case for emotional intensity. Journal of Personality and Social Psychology, 61(3), 427-434. http s: / / doi.org/10.1037 / 0022 3514.61.3.427

Garnefski, N., \& Diekstra, R. (1997). Adolescents from one parent, stepparent and intact families: emotional problems and suicide attempts. Journal of Adolescence, 202 , 201-208.

Gross, J. J. (1998). The emerging field of emotion regulation: An integrative review. Review of General Psychology, 2(3), 271-299. https://doi.org/10.1037/10892680.2.3.271

Gross, J. J. (2008). Handbook of emotions (3rd ed.). Guilford Press.

Gross, J. J., \& John, O. P. (2003). Individual differences in two emotion regulation processes: Implications for affect, relationships, and well-being. Journal of Personality and Social Psychology, 85(2), 348-362. https://doi.org/10.1037/ 0022-3514.85.2.348 
Hurlock, E. B. (1973). Adolescent development (4th ed.). McGraw-Hill Kogakusha.

IDN Times. (2019). Ada 2109 perceraian di Kota Malang perselisihan jadi faktor utama. IDN Jatim. https:// jatim.idntimes.com/news/jatim/belaikhsan-asaat/ada-2109-perceraian-dikota-malang-perselisihan-jadi-faktorutama/full. Pada 7 Januari 2020

John, O. P., \& Gross, J. J. (2004). Healthy and unhealthy emotion regulation: Personality processes, individual differences, and life span development. Journal of Personality, 72(6), 13011333. https://doi.org/10.1111/j.14676494.2004.00298.x

Kartono, K. (1997). Patologi sosial. Rajawali.

Lestari, D. W. (2014). Penerimaan diri dan strategi coping pada remaja korban perceraian orangtua. E-Journal Psikologi, 2(1), 1-13. http://e-journals.unmulac.id/ index.php/psikoneo/article/view/3515

Lucas, R. E., \& Gohm, C. . (2000). Age and sex differences in subjective well-being across cultures. In E. Diener \& E. M. Suh (Eds.), Culture and subjective well-being (pp. 291-318.).

Nansi, D., \& Utami, T. (2016). Hubungan antara regulasi emosi dengan perilaku disiplin santri madrasah aliyah pondok pesantren qodratullah langkan. Psikis: Jurnal Psikologi Islami, 2(1), 16-28. http:// jurnal.radenfatah.ac.id/index.php/ psikis/article/view/1054

Nolen-Hoeksema, S., \& Aldao, A. (2011). Gender and age differences in emotion regulation strategies and their relationship to depressive symptoms. Personality and Individual Differences, 51(6), 704-708. h ttp s: / / do i.org / 10.1016 / j.paid.2011.06.012

Pratama, G. (2019). Peran regulasi emosi terhadap prokrastinasi akademik pada siswa kelas VIII SMP. Indonesian Journal of Guidance and Counseling, 8(2), 119124. https://doi.org/10.15294/ ijgc.v8i2.19693
Ratnasari, S., \& Suleeman, J. (2017). Perbedaan regulasi emosi perempuan dan laki-laki di perguruan tinggi. Jurnal Psikologi Sosial, 15(1), 35-46. https://doi.org/ 10.7454/jps.2017.4

Rubiani, A., \& Sembiring, S. (2018). Perbedaan regulasi emosi pada remaja ditinjau dari faktor usia di sekolah Yayasan Pendidikan Islam Swasta Amir Hamzah Medan. Jurnal Diversita, 4(2), 99-108. https://doi.org/ 10.31289/diversita.v4i2.1593

Santrock, J. W. (2012). Life span development: Perkembangan masa hidup (13rd ed.). Erlangga.

Seidlitz, L., \& Diener, E. (1998). Sex differences in the recall of affective experiences. Journal of Personality and Social Psychology, 74(1), 262-271. https://doi.org/10.1037//00223514.74.1.262

Silvers, J. A., McRae, K., Gabrieli, J. D. E., Gross, J. J., Remy, K. A., \& Ochsner, K. N. (2012). Age-related differences in emotional reactivity, regulation, and rejection sensitivity in adolescence. Emotion, 12(6), 1235-1247. https://doi.org/ $10.1037 / \mathrm{a} 0028297$

Thompson, R. A. (1994). Emotion regulation: A theme in search of definition. Monographs of the Society for Research in Child Development, 59(2-3), 25-52. https://doi.org/10.1111/j.15405834.1994.tb01276.x

Urry, H. L., \& Gross, J. J. (2010). Emotion regulation in older age. Current Directions in Psychological Science, 19(6), 352-357. h ttp s: / / doi.org/10.117 / 0963721410388395

Zonya, O. L., \& Sano, A. (2019). Differences in the emotional regulation of male and female students. Jurnal Neo Konseling, 1(3), 1-5. https://doi.org/10.24036/ 00128kons2019

Received 9 July 2020 Revised 20 December 2020 Accepted 21 December 2020 
